\title{
The Use of Film-Forming Polymers to Control Guignardia Leaf Blotch and Powdery Mildew on Aesculus hippocastanum L. and Quercus robur L.
}

\author{
Glynn C. Percival, Ian P. Keary, and Kelly Marshall
}

\begin{abstract}
The effects of four commercially available film-forming polymers (Bond, Designer, Spray Gard, Nu-Film-P) on disease severity of powdery mildew (Microsphaera alphitoides Griffon and Maubl.) on English oak (Quercus robur L.) and Guignardia leaf blotch (Guignardia aesculi (Peck) Stewart) on horsechestnut (Aesculus hippocastanum L.) were examined in a field experiment. In addition, a comparative evaluation of the fungicide penconazole, commercially used for powdery mildew control, was conducted. Effects on tree vitality were also assessed by measuring leaf chlorophyll fluorescence and chlorophyll concentrations. Irrespective of tree species, Nu-Film-P and Spray Gard did not significantly influence disease severity of powdery mildew and Guignardia leaf blotch. Likewise, no significant effects of these two film-forming polymers on chlorophyll fluorescence and chlorophyll content were recorded. Reduction in disease severity following spray applications of the film-forming polymers Bond and Designer was statistically comparable with penconazole. None of the film-forming polymers and fungicide evaluated was phytotoxic to the test trees. Results suggest that application of an appropriate film-forming polymer may provide a useful addition to existing methods of plant disease control.
\end{abstract}

Key Words. Disease control; foliar pathogens; fungicides; integrated disease management; urban trees.

Horsechestnut (Aesculus hippocastanum L.) and English oak (Quercus robur L.) are two commonly planted tree species in U.K. urban landscapes (Hodge 1991). Both are susceptible to attack by the foliar diseases Guignardia leaf blotch (Guignardia aesculi (Peck) Stewart) and powdery mildew (Microsphaera alphitoides Griffon and Maubl.), respectively (Agrios 2004). Damage caused by Guignardia leaf blotch first appears as small water-soaked areas on the leaf surface that turn reddish brown. Such lesions are often surrounded by a yellow border that may fade during lesion development. Small black spots may also appear on the brown infected areas. The size of the lesions varies greatly, and while the growth of small lesions may be inhibited by the presence of leaf veins, larger lesions often merge together, which results in the leaves curling upward. Disease severity can sometimes be so severe that total defoliation of trees can be observed by late July to early August (Strouts and Winter 2000). Symptoms of powdery mildew attack include slightly raised blisterlike areas on the leaf surface that become covered with a white to gray powdery growth. Stunting and distortion of developing leaves and stems usually accompany these symptoms. Leaves eventually become chlorotic and fall. This type of infection manifests itself as a loss of photosynthetic leaf area and photosynthetic rate (Hibbard et al. 1996, Sabri et al. 1997; Sutherland and Walters 2002).

Control of Guignardia leaf blotch is limited because of the lack of any U.K.-registered fungicides (British Crop Protec- tion Council 2005). Consequently, control is restricted to sanitation measures such as leaf removal in autumn to reduce the amount of disease inoculum available the following spring. In the case of powdery mildew, a limited number of fungicides have been registered for use within the United Kingdom. However, application of fungicides to control powdery mildew has limitations. The buildup of tolerance to fungicides by powdery mildew has been reported (Agrios 2004). Likewise, fungicidal control of powdery mildew is difficult once a tree is heavily infected. Finally, concerns regarding the environmental fate of agrochemicals in urban landscapes have meant that, due to government legislative restrictions, the use and application of fungicides is strictly regulated. Consequently, new techniques of disease control are now of importance (Schneider et al. 1997; Christiansen et al. 1999; Percival 2001).

Film-forming polymers are widely used as spray adjuvants within the agricultural and horticultural industries (Backman 1978). Their main functions are to reduce weathering and extend pesticide efficacy, as well as act as stickers/spreaders to improve the distribution and adherence of agrochemicals and antitranspirants to decrease water loss and wilting (Gale and Hagan 1996). Subsequent studies have found that filmforming polymers can be applied as protective barriers over leaf surfaces to protect tissue against invading foliar diseases (Han 1990). For example, film-forming polymers have been shown to be useful in controlling pathogenic fungi such as 
rust (Puccinia, Uromyces spp.), gray mold (Botrytis cinerea Pers.), eyespot (Septoria nodorum Berk.), and leaf spot (Pyrenophora spp.), economically important diseases of cereals, vegetables, fruit, and ornamentals (Marco et al. 1994; Sutherland and Walters 2001, 2002). Little scientific investigation into film-forming polymers to control foliar diseases of urban trees has occurred. Consequently, the aim of this study was to determine the effect of four commercially available filmforming polymers on Guignardia leaf blotch of horsechestnut and powdery mildew infection of English oak.

\section{MATERIALS AND METHODS}

\section{Plant Material and Experimental Design}

The experiment used 3-year-old, bare-rooted stock of horsechestnut (Aesculus hippocastanum L.) and English oak (Quercus robur L.) obtained from a local supplier. Trees were planted directly into the ground by hand in early November 2001 and left to establish throughout the 2002 and 2003 growing season. The trial site was located at the University of Reading Shinfield Experimental Site, Berkshire. Planting distances were $1 \times 1 \mathrm{~m}(3.3 \times 3.3 \mathrm{ft})$. Supplementary irrigation was applied during the 2002 and 2003 growing season, and trees were fertilized annually via a broadcast application of granular N:P:K (29:7:9) fertilizer (Bartlett BOOST, Doggett Corp., Lebanon, NJ) applied at $40 \mathrm{~g} / \mathrm{m}^{2}\left(1.4 \mathrm{oz} / 11 \mathrm{ft}^{2}\right)$ in early May. No watering or fertilization was applied during the 2004 trial. The soil was a sandy loam containing $4 \%$ to $6 \%$ organic matter, $\mathrm{pH}$ 6.2; available $\mathrm{P}, \mathrm{K}, \mathrm{Mg}, \mathrm{Na}$, and $\mathrm{Ca}$ levels were 52, 659.1, 175.2, 49.4, and $2188 \mathrm{mg} / \mathrm{L}(0.0001$, $0.005,0.002,0.0001,0.02 \mathrm{oz} /$ gallon), respectively, at the time treatments commenced (May 2004). Weeds were controlled chemically using glyphosate (Roundup; Green-Tech, Sweethills Park, Nun Monkton, York) from the day of planting, November 2001, to the cessation of the experiment, September 2004.

Historically, both horsechestnut and English oak suffered heavily from Guignardia leaf blotch and powdery mildew infection, respectively, on an annual basis. Consequently, prior to the trial commencing in 2004, trees were inspected in September 2003, and only those trees rated with a disease severity of $4(51 \%$ to $80 \%$ of leaves affected, severe foliar discoloration) were used in the trial. A minimal insecticide program based on the residual pyrethroid insecticide deltamethrin (Bandu, Headland Agrochemicals Ltd., Saffron Walden, Essex) was applied every 3 months during each growing season commencing in May 2002 to September 2004. All sprays were applied using a Tom Wanner Spray Rig sprayer at $40 \mathrm{~mL}(1.2 \mathrm{fl} \mathrm{oz})$ deltamethrin (Bandu) per $100 \mathrm{~L}(26 \mathrm{gal})$ of water. Trees were sprayed until runoff, generally $0.25 \mathrm{~L}$ (0.07 gal) insecticide per tree.

The experimental design was a randomized complete block with five single-tree replications. All treatments commenced under field conditions in early May 2004, when both test species were in full leaf, and treatments were repeated in early June. To keep the physiological age of the leaves comparable throughout the experiment, measurements of chlorophyll fluorescence and chlorophyll content (SPAD) were made only on fully expanded 21 to 28 day old leaves. In all cases, chlorophyll fluorescence and SPAD measurements were taken from six leaves (two from the top of the crown, two in the center, and two at the base) per tree. Leaves were tagged to ensure that the same leaves were measured throughout the experimental period.

\section{Treatments}

Prior to film-forming polymer sprays, polythene screens $1 \mathrm{~m}$ (3.3 ft) high were erected around each tree to prevent dispersal of sprays and possible cross-contact with other trees, and the base of the tree was covered with a $0.5 \times 0.5 \mathrm{~m}(1.65$ $\times 1.65 \mathrm{ft}$ ) polythene mulch to prevent percolation into the soil.

\section{Film-Forming Polymers}

Foliar sprays of the film-forming polymers Bond (active ingredient [a.i.] alkyl phenyl hydroxyl polyoxyehtylene), Designer (a.i. styrene-butadiene copolymer + polyalkylene oxide modified heptamethyl trisiloxane), Nu-Film P (a.i. poly1-p menthene), and Spray Gard (a.i. di-1-p menthene) were applied until runoff using a hand-sprayer at a concentration of $10 \mathrm{~mL}(0.3 \mathrm{fl} \mathrm{oz})$ per liter $(0.26 \mathrm{gal})$ of water. Ten $\mathrm{mL}(0.3 \mathrm{fl}$ oz) per liter (0.26 gal) of water was selected as a foliar spray concentration based on results of a preliminary trial to determine the maximal concentration of film-forming polymer that could be applied to leaf tissue without the onset of phytotoxicity damage (data not shown). All film-forming polymers were obtained from United Agri Products Ltd. (Alconbury Weston, Huntingdon). In addition, a comparative evaluation of the fungicide Topas (a.i. penconazole), a protectant conazole fungicide with antisporulant activity (Syngenta Crop Protection UK Ltd., Whittlesford, Cambridge), commercially used for powdery mildew control, was conducted by spraying trees at the manufacturer's recommended rate of $1.5 \mathrm{~mL}$ ( $0.045 \mathrm{fl} \mathrm{oz})$ per liter $(0.26 \mathrm{gal})$ of water.

\section{Chlorophyll Fluorescence}

Fluorescence values were obtained by placing leaves in darkness for 30 min by attaching light exclusion clips to the leaf surface of whole trees, and chlorophyll fluorescence was measured using a HandyPEA portable fluorescence spectrometer (Hansatech Instruments Ltd., King's Lynn). Measurements were recorded up to $1 \mathrm{sec}$ with a data acquisition rate of $10 \mu \mathrm{s}$ for the first $2 \mathrm{~ms}$ and of $1 \mathrm{~ms}$ thereafter. The fluorescence responses were induced by a red (peak at 660 $\mathrm{nm})$ light of $1500 \mu \mathrm{mol} \mathrm{m}{ }^{-2} \mathrm{~s}^{-1}$ photosynthetically active radiation (PAR) intensity provided by an array of six red light-emitting diodes. The ratio of variable $(\mathrm{Fv}=\mathrm{Fm}-\mathrm{Fo})$ to maximal (Fm) fluorescence (i.e., $\mathrm{Fv} / \mathrm{Fm}$ ), which represents 
the maximum quantum yield of photosystem II, which in turn is highly correlated with the quantum yield of net photosynthesis, regarded as a measure of tree vitality, was recorded (Maxwell and Johnson 2001).

\section{Chlorophyll Measurements}

A Minolta chlorophyll meter, SPAD-502, was used. Chlorophyll was measured at the midpoint of the leaf next to the main leaf vein. Calibration was obtained by measurement of absorbance at 663 and $645 \mathrm{~nm}$ in a spectrophotometer (PU8800 Pye Unicam) after extraction with $80 \% \mathrm{v} / \mathrm{v}$ aqueous acetone (regr. eq. $=5.80+0.057 x ; r^{2}$ adj. $=0.82, P<0.01$ ) (Lichtenthaler and Wellburn 1983).

\section{Disease Severity}

Disease severity was assessed visually on 27 September 2004. Each tree was rated on a 0 to 5 rating scale using a visual indexing technique and ratings on the scale: $0=$ no powdery mildew or leaf blotch observed; $1=$ less than $5 \%$ of leaves affected and no aesthetic impact; $2=5 \%$ to $20 \%$ of leaves affected with some yellowing but little or no defoliation; $3=21 \%$ to $50 \%$ of leaves affected, significant defoliation and/or leaf yellowing; $4=51 \%$ to $80 \%$ of leaves affected, severe foliar discoloration; $5=81 \%$ to $100 \%$ of foliage affected with $90 \%$ to $100 \%$ defoliation. The individual ratings for each tree in each treatment were used as a disease severity for statistical analysis.

\section{RESULTS}

Irrespective of tree species, the film-forming polymers $\mathrm{Nu}$ Film-P and Spray Gard did not significantly influence disease severity of powdery mildew and Guignardia leaf blotch (Figures 1 and 4). Likewise, no significant effects of these two film-forming polymers on leaf $\mathrm{Fv} / \mathrm{Fm}$ values as a measure of tree vitality (Figures 2 and 5) and SPAD values as a measure of leaf chlorophyll content (Figures 3 and 6) compared to controls were recorded. In 2004, damaging outbreaks of powdery mildew and Guignardia leaf blotch were recorded on control trees, as indicated by disease severity ratings of 4.33 and 4.67, respectively, on leaves of English oak and horsechestnut (Figures 1 and 4). Increased disease severity on controls was mirrored by reduced leaf $\mathrm{Fv} / \mathrm{Fm}$ and SPAD values (Figures 2, 3, 5, and 6). During the study, none of the treated or control trees died as a result of pathogen attack. None of the film-forming polymers and fungicide evaluated was phytotoxic to the test trees.

\section{English Oak (Quercus robur L.)}

Disease severity of powdery mildew on leaves was reduced by $15 \%$ to $54 \%$ compared to control trees following spray applications of Bond, Designer, and penconazole at the cessation of the 2004 growing season (Figure 1). In the case of Bond and penconazole, the reduction in disease severity was

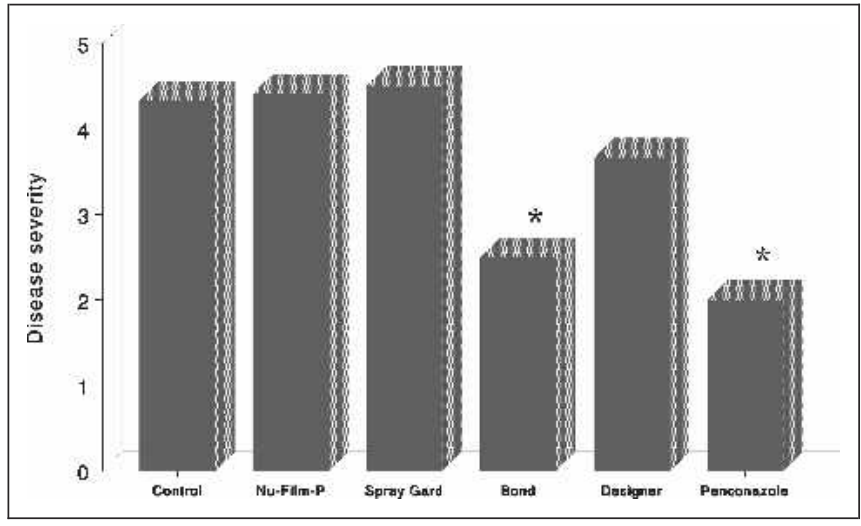

Figure 1. Influence of film-forming polymers and a fungicide treatment on disease severity of powdery mildew on English oak growing under field conditions. All values mean of five trees. Asterisk indicates values significantly different from controls according to LSD (0.702) at $P<$ 0.05 ; no annotation indicates values not significantly different from control value. Significance of film-forming polymer $P<0.001$ (ANOVA effect).

significant from controls at $P<0.05$. Spray applications with the film-forming polymer Designer reduced disease severity in comparison with control trees, but not significantly so (Figure 1). Higher Fv/Fm (18\% to $21 \%$ ) and SPAD values ( $34 \%$ to $81 \%$ ) compared to controls were recorded in Bondand penconazole-treated trees (Figures 2 and 3). In both cases, such increases were significant $(P<0.05)$. Spray application of the film-forming polymer Designer significantly $(P<0.05)$

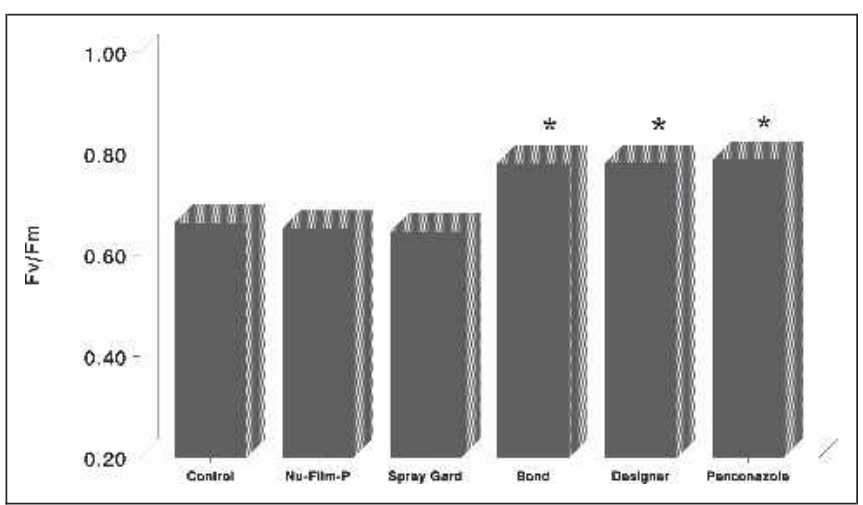

Figure 2. Influence of film-forming polymers and a fungicide treatment on tree vitality of English oak as measured by chlorophyll fluorescence $\mathrm{Fv} / \mathrm{Fm}$ ratios growing under field conditions following powdery mildew infection. All values mean of five trees, six leaves per tree. Asterisk indicates values significantly different from controls according to LSD (0.0754) at $P<0.05$; no annotation indicates values not significantly different from control value. Significance of film-forming polymer $P<0.001$ (ANOVA effect). 


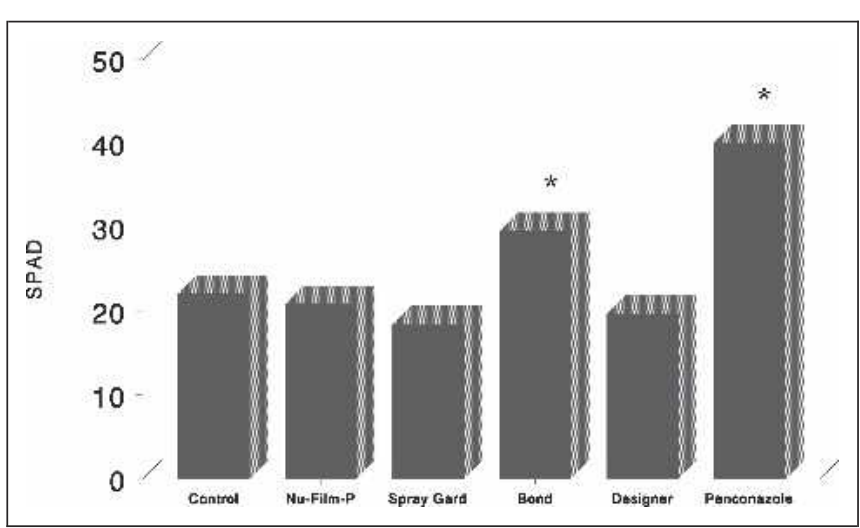

Figure 3. Influence of film-forming polymers and a fungicide treatment on leaf chlorophyll content of English oak growing under field conditions following powdery mildew infection as measured by a handheld SPAD meter. All values mean of five trees, six leaves per tree. Asterisk indicates values significantly different from controls according to LSD (5.1 18) at $P<0.05$; no annotation indicates values not significantly different from control value. Significance of film-forming polymer $P<0.001$ (ANOVA effect).

increased Fv/Fm values, but SPAD values as a measure of leaf chlorophyll content were not significantly affected. Spray applications of the fungicide penconazole provided a greater degree of powdery mildew control compared to all four film-forming polymers used in this investigation, based on lower leaf disease severity values and higher leaf Fv/Fm ratios and SPAD measurements (Figures 1, 2, and 3).

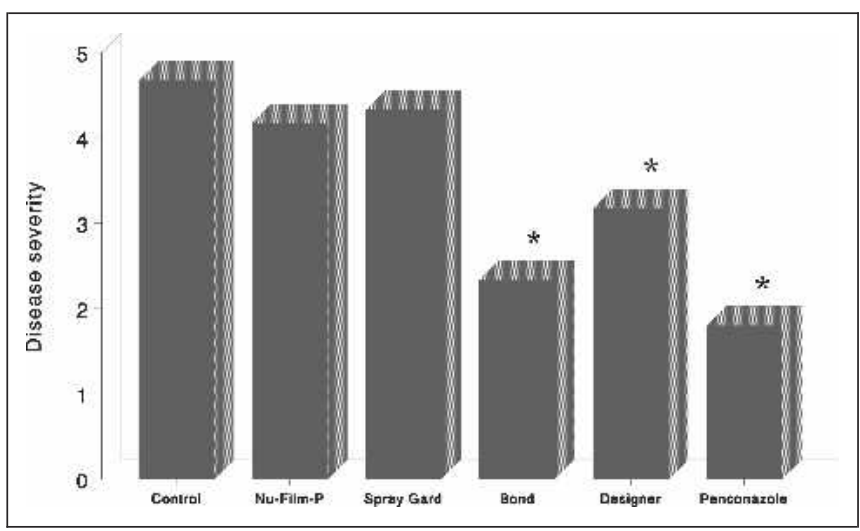

Figure 4. Influence of film-forming polymers and a fungicide treatment on disease severity of Guignardia leaf blotch on horsechestnut growing under field conditions. All values mean of five trees. Asterisk indicates values significantly different from controls according to LSD (0.802) at $P<0.05$; no annotation indicates values not significantly different from control value. Significance of film-forming polymer $P<0.001$ (ANOVA effect).

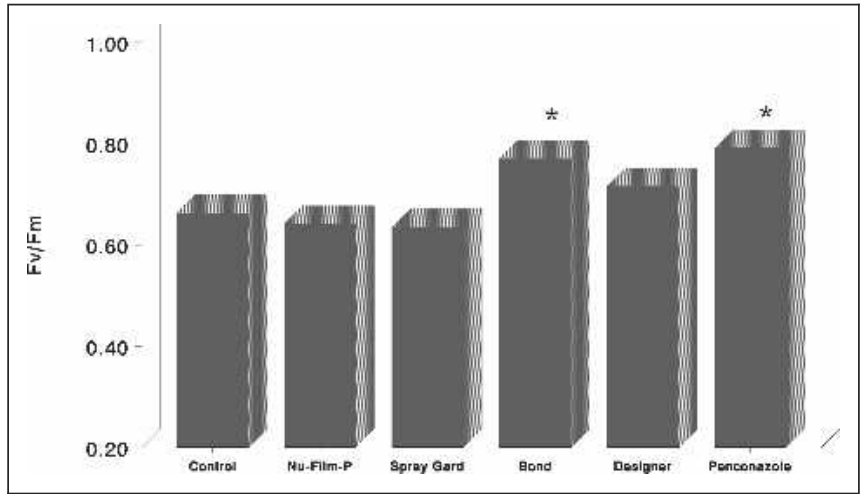

Figure 5. Influence of film-forming polymers and a fungicide treatment on tree vitality of horsechestnut oak as measured by chlorophyll fluorescence Fv/Fm ratios growing under field conditions following Guignardia leaf blotch infection. All values mean of five trees, six leaves per tree. Asterisk indicates values significantly different from controls according to LSD $(0.103)$ at $P<0.05$; no annotation indicates values not significantly different from control value. Significance of film-forming polymer $P<0.015$ (ANOVA effect).

\section{Horsechestnut (Aesculus hippocastanum L.)}

After Bond, Designer, and penconazole treatment, disease severity on leaves was significantly reduced $(P<0.05)$ by $32 \%$ to $54 \%$ of the control value at the cessation of the experiment (Figure 4). Likewise, increased Fv/Fm and SPAD values of $7 \%$ to $17 \%$ and $24 \%$ to $43 \%$, respectively, over

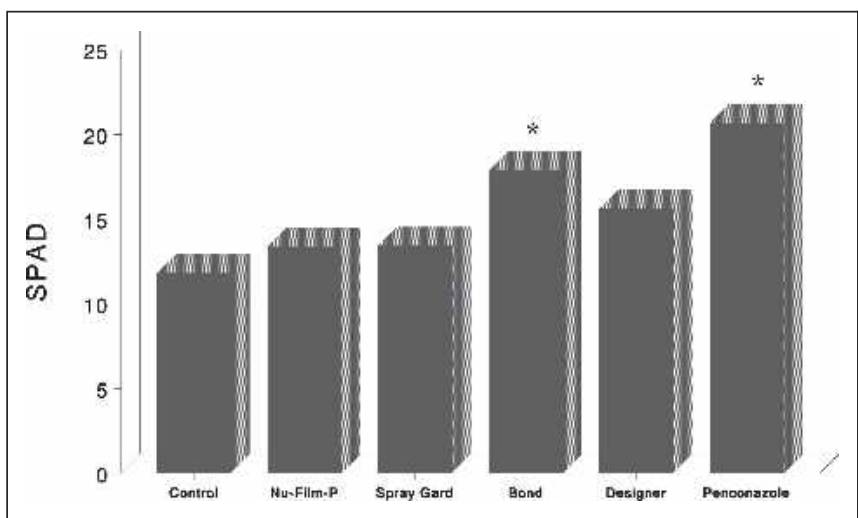

Figure 6. Influence of film-forming polymers and a fungicide treatment on leaf chlorophyll content of horsechestnut growing under field conditions following Guignardia leaf blotch infection as measured by a handheld SPAD meter. All values mean of five trees, six leaves per tree. Asterisk indicates values significantly different from controls according to LSD (3.910) at $P<0.05$; no annotation indicates values not significantly different from control value. Significance of film-forming polymer $P<0.001$ (ANOVA effect). 
controls were recorded in trees treated with Bond, Designer, and penconazole (Figures 5 and 6). In the case of Bond and penconazole treatment, increases in $\mathrm{Fv} / \mathrm{Fm}$ and SPAD values were significantly higher than controls. In the case of Designer, values were higher than controls, but not significantly so (Figures 5 and 6). Differences in the magnitude of the degree of protection conferred were recorded. Based on reductions in leaf disease severity values and higher leaf $\mathrm{Fv} / \mathrm{Fm}$ ratios and SPAD measurements, efficacy of protection was in the order penconazole $>$ Bond $>$ Designer (Figures 4, 5, and 6).

\section{DISCUSSION}

The data show that two (Bond, Designer) of the four filmforming polymers provided significant control of powdery mildew and Guignardia leaf blotch infection of English oak and horsechestnut, respectively, in field experiments. Although film-forming polymers have been shown to provide a significant degree of control of many foliar diseases such as powdery mildew, leaf spot, rusts, and gray mold, results in the majority of cases were derived from cereal crops, primarily under glasshouse conditions (Ziv and Hagiladi 1984; Elad et al. 1990; Zekaria-Oren and Eyal 1991; Walters 1992; Sutherland and Walters 2002). Results of this investigation show that film-forming polymers have disease control potential under field conditions. In addition, the application of the film-forming compounds to both tree species in the field produced no phytotoxic effects on leaf tissue. For example, higher Fv/Fm chlorophyll fluorescence ratios on Bond- and Designer-treated trees and Fv/Fm ratios of Spray Gard- and $\mathrm{Nu}-$ Film-P-treated trees comparable with controls suggest that the compounds had no detrimental effects on rates of photosynthesis and leaf expansion. Chlorophyll fluorescence Fv/Fm ratios have been shown to be highly sensitive to damage to the leaf photosynthetic apparatus in response to a range of stimuli such as salt, heat, and chemical and atmospheric pollutants and are consequently widely used as a noninvasive measure of tree vitality (Haldimann and Strasser 1999; Popovic et al. 2003; Percival 2004).

In general, disease severity of powdery mildew and Guignardia leaf blotch was reduced by $15 \%$ to $54 \%$ and $32 \%$ to $54 \%$, respectively, following application with the filmforming polymers Bond and Designer. Such results are in agreement with previous work showing control of powdery mildew infection of barley under glasshouse and field conditions by $70 \%$ to $85 \%$ and $50 \%$ to $65 \%$, respectively, using menthene-based film-forming polymers such as Ethokem, Bond, and Vapor Gard (Sutherland and Walters 2002). Similar control percentages of powdery mildew infection of wheat by menthene and wax emulsion-based film-forming polymers in the field were recorded by Ziv and Frederiksen (1987). In the case of Zekaria-Oren and Eyal (1991), greater than 80\% suppression of leaf rust (Puccinia recondita f. sp. tritici) was achieved using the film-forming polymers Bio-Film, Folicote, and Vapor Gard under glasshouse conditions, with little difference in efficacy recorded between preventive and therapeutic film-forming polymer treatments.

Many studies suggest that the ability of film-forming polymers to control foliar pathogens is due to enhancement of natural defenses at the leaf surface (Gale and PoljakoffMayber 1962; Ziv and Frederiksen 1983). Alternately, Osswald et al. (1984) reported that adherence of spores to the polymer-coated surface prevented development of germ tubes and was a primary factor in reducing disease severity. Other work suggested that film-forming polymers increase thickness, hardness, and resistance to enzymatic degradation of the epicuticular wax layer, thus increasing impenetrability of the leaf surface (Elad et al. 1990). Zekaria-Oren and Eyal (1991) found that film-forming polymers affected successful orientation of germinating urediniospores and development of appressoria. They suggested this could be due to suppression of stimuli at the leaf surface by the formation of a physical barrier between the invading pathogen and the host plant. It has also been suggested that film-forming polymers may subtly alter the topography of the leaf surface, thus interfering with fungal recognition of host penetration sites - that is, the potentially invading fungus is unaware that it is on a host plant (Zekaria-Oren and Eyal 1991). Although certain filmforming polymers may be biologically inert and act by purely physical mechanisms, there is evidence that suggests that some may have direct fungicidal or fungistatic properties (Elad et al. 1989, 1990; Zekaria-Oren and Eyal 1991). Work by Sutherland and Walters (2002) found that the film-forming polymers Bond and Vapor Gard reduced germination of powdery mildew conidia and the subsequent formation of appressoria and haustoria. Such a response was in accordance with previous work that showed that the film-forming polymers Bond and Vapor Gard reduced mycelial growth of leaf spot of oat (Pyrenophora avenae Ito and Kuribayashi) and rice blast (Pyricularia oryzae Cav.) in vitro. Microscopic observations reported changes in fungal morphology to include swollen shorter fungal cells, granulation of cytoplasm, and collapsed empty cells (Sutherland and Walters 2001). Importantly, all available information suggests that film-forming polymers achieve disease control via multiple defense mechanisms; this in turn makes it highly unlikely that a pathogen can readily develop resistance to such a control measure.

In this investigation marked differences were observed in the degree of control obtained between film-forming polymers. In the case of Nu-Film-P and Spray Gard, no beneficial effects were obtained. Both Nu-Film-P and Spray Gard (poly1-p menthene and di-1-p menthene, respectively) have been used for many years primarily as antitranspirants to decrease water loss and wilting of commercially important forestry transplants, as well as extending pesticide efficacy. However, the recent generation of film-forming polymers (Bond, De- 
signer) contains different active ingredients from the original film-forming polymers that are more stable and nontoxic to leaf tissue (Fuller et al. 2003). One important property of film-forming polymers is their ability to stretch during leaf expansion. Although not investigated in this experiment, greater stretching properties of Bond and Designer over $\mathrm{Nu}-$ Film-P and Spray Gard might as a result protect leaf surfaces for a longer period and in addition newly expanded leaf tissue, accounting for the marked degree of protection recorded (Sutherland and Walters 2002).

Although the level of disease control achieved was statistically comparable with a currently used triazole-based fungicide, maximal reductions in disease severity against powdery mildew and Guignardia leaf blotch were obtained using penconazole fungicide sprays. In the case of the film-forming polymer Bond, disease severity of powdery mildew fell from 4.3 to 2.5 and Guignardia leaf blotch from 4.7 to 2.3. In the case of penconazole, disease severity of powdery mildew fell from 4.3 to 2.0 and Guignardia leaf blotch from 4.7 to 2.2. Such a result gives credence to the potential of film-forming polymers as an alternative or complement to conventional fungicides. Because film-forming polymers are biologically inert and act by physical means, they are not, at least in the United Kingdom, subject to the stringent legislative restrictions relating to the use and application of conventional pesticides that act by chemical means. This also means that film-forming polymers can be used to control foliar diseases of urban trees for which no pesticides are registered. This would be of fundamental importance in the United Kingdom, where diseases such as anthracnose of willow (Marssonina salicicola (Bres.) Magnus) and London plane (Apiognomonia veneta (Sacc. et Speg. Hohnel), leaf spot of cherry (Blumeriella jaapii (Rehm) v. Arx.), and blossom wilt of cherry (Monilinia laxa (Aderh. and Ruhland) Honey) are increasing in severity on an annual basis, resulting in substantial mortality rates of infected trees. Likewise, film-forming polymers cost in general $40 \%$ to $80 \%$ less than conventional fungicides. Viewed in this context, the development of novel types of film-forming polymers may provide a useful addition to existing methods of plant disease control.

Acknowledgment. The authors are grateful for funding in part from the Tree Fund (Hyland Johns Grant).

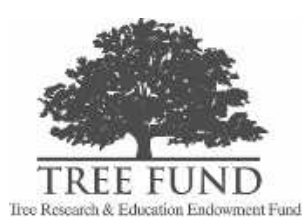

\section{LITERATURE CITED}

Agrios, G.N. 2004. Plant Pathology, 5th ed. Academic Press, San Diego, CA.

Backman, P.A. 1978. Fungicide formulation: Relationship to biological activity. Annual Review of Phytopathology 16: 211-237.
British Crop Protection Council. 2005. U.K. Pesticide Guide. Cabi Publishing, Oxford, U.K.

Christiansen, E., P. Karokene, A.A. Berryman, V.R. Franceschi, T. Krekling, F. Lieutier, A. Lonneborg, and H. Solheim. 1999. Mechanical injury and fungal infection induce acquired resistance in Norway spruce. Tree Physiology 19:399-403.

Elad, Y., N. Aynish, O. Ziv, and J. Katan. 1990. Control of grey mould (Botrvtis cinerea) with film-forming polymers. Plant Pathology 39:249-254.

Elad, Y., O. Ziv, N. Aynish, and J. Katan. 1989. The effect of film-forming polymers on powdery mildew of cucumber. Phytoparasitica 17:279-288.

Fuller, M.P., F. Hamed, M. Wisniewski, and D.M. Glenn. 2003. Protection of plants from frost using hydrophobic particle film and acrylic polymer. Annals of Applied Biology 143:93-97.

Gale, J., and R.M. Hagan. 1996. Plant antitranspirants. Annual Review of Plant Physiology 17:269-282.

Gale, J., and A. Poljakoff-Mayber. 1962. Prophylactic effect of a plant antitranspirant. Phytopathology 52:715-717.

Haldimann, P., and R.J. Strasser. 1999. Effects of anaerobiosis as probed by the polyphasic chlorophyll and fluorescence rise kinetic in pea (Pisum sativum L.). Photosynthesis Research 62:67-83.

Han, J. 1990. Use of antitranspirant epidermal coatings for plant protection in China. Plant Disease 74:263-266.

Hibbard, J.M., P. Richardson, and R. Whitbread. 1996. Effects of leaf age, basal meristem and infection with powdery mildew on photosynthesis in barley grown in 700 $\mu \mathrm{mol} \mathrm{mol}{ }^{-1} \mathrm{CO}_{2}$. New Phytologist 134:317-325.

Hodge, S.J. 1991. Urban Trees; a Survey of Street Trees in England. Forestry Commission Bulletin 99, HMSO, London, U.K.

Lichtenthaler, H.K., and A.R. Wellburn. 1983. Determinations of total carotenoids and chlorophylls $\mathrm{a}$ and $\mathrm{b}$ of leaf extracts in different solvents. Biochemical Society Transcripts 11:591-593.

Marco, S., O. Ziv, and R. Cohen. 1994. Suppression of powdery mildew in squash by applications of whitewash, clay and antitranspirant materials. Phytoparasitica 22:19-29.

Maxwell, K., and G.N. Johnson. 2001. Chlorophyll fluorescence: A practical guide. Journal of Experimental Botany 51:659-668.

Osswald, W., M. Niehuss, W. Huber, and E.F. Elstner. 1984. Support of non-host resistance by artificial leaf coating. Journal of Plant Disease Protection 91:337-344.

Percival, G.C. 2001. Induction of systemic acquired disease resistance in plants: potential implications for disease management in urban forestry. Journal of Arboriculture 27(4):181-193. . 2004. Evaluation of physiological tests as predictors 
of young tree establishment and growth. Journal of Arboriculture 30(2):80-92.

Popovic, R., D. Dewez, and P. Juneau. 2003. Applications of chlorophyll fluorescence in ecotoxicology: Heavy metals, herbicides, and air pollutants, pp. 151-184. In Practical Applications of Chlorophyll Fluorescence in Plant Biology. DeEll, J.R., and Toivonen, P.M.A., Eds. Kluwer Academic Publishers, London, U.K.

Sabri, N., P.J. Dominy, and D.D. Clarke. 1997. The relative tolerances of wild and cultivated oats to infection by Erysiphe graminis f.sp. avanae: II. The effects of infection on photosynthesis and respiration. Physiological and Molecular Plant Pathology 50:321-335.

Schneider, M., P. Schweizer, P. Meuwly, and J.P. Metraux. 1997. Systemic acquired resistance in plants. International Review of Cytology 168:303-340.

Strouts, R.G., and T.G. Winter. 2000. Diagnosis of Ill-Health in Trees. HMSO, The Stationary Office, Norwich, U.K.

Sutherland, F., and D.R. Walters. 2001. In vitro effects of film-forming polymers on the growth and morphology of Pvrenophora avenae and Pyricularia oryzae. Journal of Phytopathology 149:621-624.

- 2002. Effect of film-forming polymers on infection of barley with the powdery mildew fungus, Bulmeria graminis f. sp. hordei. European Journal of Plant Pathology 108:385-389.

Walters, D.R. 1992. The effects of three film-forming polymers, with and without a polyamine biosynthesis inhibitor, on powdery mildew infection of barley seedlings. Annals of Applied Biology 120:41-46.

Zekaria-Oren, J., and Z. Eyal. 1991. Effect of film-forming compounds on the development of leaf rust on wheat seedlings. Plant Disease 75:231-234.

Ziv, O., and R.A. Frederiksen. 1983. Control of foliar diseases with epidermal coating materials. Plant Disease 67: 212-214.

- 1987. The effect of film-forming antitranspirants on leaf rust and powdery mildew incidence on wheat. Plant Pathology 36:242-245.

Ziv, O., and A. Hagiladi. 1984. Control of powdery mildew on hydrangea and crapemyrtle with antitranspirants. HortScience 19:708-709.

Glynn C. Percival (corresponding author)

Plant Physiologist/Technical Support Specialist

R.A. Bartlett Tree Research Laboratory, Europe

The University of Reading

2 Early Gate, Whiteknights

Reading, RG6 6AU, United Kingdom

gpercival@Bartlettuk.com or glynn.percival@tesco.net
Ian P. Keary

Research Assistant and Ph.D. Candidate

R.A. Bartlett Tree Research Laboratory, Europe

The University of Reading

2 Early Gate, Whiteknights

Reading, RG6 6AU, United Kingdom

Kelly Marshall

Research Assistant, Arboriculture Section

Myerscough College

Bilsborrow, Preston, United Kingdom

Résumé. Les effets de quatre films de polymères disponibles commercialement (Bond, Designer, Spray Gard, Nu-Film-P) par rapport au degré de sévérité du blanc des feuilles (Microsphaera alphitoides Griffon and Maubl.) ont été vérifiés sur le chêne anglais (Quercus robur L.) ainsi que chez le marronnier d'Inde (Aesculus hippocastanum L.) dans le cas de la brûlure des feuilles du marronnier (Guignardia aescu/i (Peck) Stewart), et ce lors de tests en champs. De plus, une évaluation comparative a été faite avec le fongicide penconazole, un produit commercialement utilisé pour le contrôle du blanc des feuilles. Les effets sur la vitalité de l'arbre ont aussi été évalués au moyen de mesures de la fluorescence de la chlorophylle et des concentrations en chlorophylle. Peu importe l'espèce de l'arbre, le Nu-Film-P et le Spray Gard n'avaient aucune influence significative sur le degré de sévérité du blanc des feuilles et de la brûlure des feuilles du marronnier. En outre, aucun effet significatif de ces deux films de polymères n'a été enregistré par rapport à la fluorescence de la chlorophylle et le contenu en chlorophylle. Des réductions statistiquement similaires quant au degré de sévérité des maladies ont été enregistrées suivant l'application par vaporisation des films de polymères Bond et Designer, et ce par rapport à l'utilisation du penconazole. Aucun des films de polymères ou fongicide utilisés n'était phytotoxique pour les arbres testés. Les résultats suggèrent que l'application d'un film approprié de polymère peut s'avérer un atout additionnel utile aux méthodes existantes de contrôle de maladies sur les végétaux.

Zusammenfassung. In einem Feldexperiment wurde der Einfluss von 4 kommerziell erhältlichen Filmbildenden Polymeren auf den Krankheitsbefall durch Mehltau bei Quercus robur L. und Blattflecken bei Aesculus hippocastanum L. untersucht. Zusätzlich wurde eine vergleichende Bewertung von Fungiziden, die gewöhnlich bei Mehltau eingesetzt werden, durchgeführt. Die Auswirkungen auf die Baumvitalität wurden auch durch Messungen der Blattchlorophyllfluoreszenz und die Chlorophyllkonzentration untersucht. Unabhängig von der Baumart konnten Nu-Film-P und Spray-Gard die Krankheitsschwere bei beiden Krankheiten nicht besonders beeinflussen. Entsprechend konnten keine besonderen Einflüsse dieser beiden Filmbildenden Polymere bei der Blattchlorophyllfluoreszenz und der Chlorophyllkonzentration aufgezeichnet werden. Der Krankheitsrückgang nach der Spray-Applikation von Bond und Designer war vergleichbar mit den Einsatz von dem Fungizid Penconazol. Keins der getesteten Filmbildenden Polymere und Fungizide war phytotoxisch bei den Testbäumen. Die Ergebnisse zeigten, dass die Applikation von einem angemessenen Filmbildenden Poly- 
mer eine nützliche Ergänzung zu bereits bestehenden Methoden der Krankheitskontrolle darstellt.

Resumen. En un experimento de campo se examinó el efecto de cuatro polímeros comercialmente disponibles (Bond, Designer, Spray Gard y Nu-Film-P) para controlar la severidad de las enfermedades por la cenicilla polvorosa (Microsphaera alphitoides Griffon and Maubl.) en Quercus robur L. y la mancha foliar (Guignardia aescu/i (Peck) Stewart) en Aesculus hippocastanum L. Además se llevó a cabo una evaluación comparativa del fungicida penconazole, comercialmente utilizado para el control de la cenicilla. Los efectos sobre la vitalidad de los árboles fueron también medidos a través de las concentraciones y fluorescencia de clorofila. Sin importar la especie de árbol, Nu-Film-P y Spray Gard no influyeron significativamente en la severidad de la cenicilla y la mancha foliar. De la misma manera, no se registraron efectos significativos de estos dos polímeros sobre el contenido y fluorescencia de clorofila. Después de la aplicación de los polímeros Bond y Designer las reducciones en la severidad de la enfermedad fueron estadísticamente comparables con penconazole. Ninguno de los polímeros y fungicidas evaluados fueron fitotóxicos para los árboles. Los resultados sugieren que la aplicación de una película de polímero puede resultar útil como método de control de enfermedades de la planta. 